\title{
Effect of Catecholestrogens on Mortality and Liver Lipid Peroxide Level of Mice Irradiated with ${ }^{60} \mathrm{Co} \boldsymbol{\gamma}$-Ray
}

\author{
Akira Tomatsu, ${ }^{1}$ Sadaaki Komura, ${ }^{2}$ Nobuko OHISHI, ${ }^{2}$ \\ Masami NAKANISHI, ${ }^{1}$ and Kunio YAGI $^{2, *}$ \\ ${ }^{1}$ Department of Obstetrics and Gynecology, Aichi Medical University, \\ Nagakute, Aichi 480-11, Japan \\ ${ }^{2}$ Institute of Applied Biochemistry, Yagi Memorial Park, \\ Mitake, Gifu 505-01, Japan
}

(Received February 24, 1993)

\begin{abstract}
Summary When 10 weeks old male BALB/c mice received wholebody irradiation with an 8 -Gy single dose of ${ }^{60} \mathrm{Co} \gamma$-ray, the survival rate 30 days after the irradiation was only $5 \%$, while the survival rate was increased to $70 \%$ when the mice were subcutaneously injected with catecholestrogen 2-hydroxyestradiol $\left(2-\mathrm{OHE}_{2}\right) 3 \mathrm{~h}$ before and $3 \mathrm{~h}$ after the irradiation. The survival rates of the mice given other test compounds were as follows: 2-hydroxyestrone, 20\%; 2-hydroxyestriol, 20\%; 4-hydroxyestradiol, 0\%; 2-methoxyestrone, 0\%; 2-methoxyestradiol, 0\%; 2-methoxyestriol, $0 \%$; estrone, $0 \%$; estradiol, $5 \%$; and estriol, $20 \%$. Upon the irradiation, lipid peroxide levels in the liver of the animals markedly increased 4 days after the irradiation. This increase in the level was significantly suppressed by the subcutaneous injection of $2-\mathrm{OHE}_{2}$. These results indicate that $2-\mathrm{OHE}_{2}$ has a protective effect against radiation injury.
\end{abstract}

Key Words: catecholestrogens, radiation injury, mortality, lipid peroxide level

It has been accepted that lipid peroxides are causative of degenerative diseases such as atherosclerosis [1-3] and cataract [4-6] and aging itself [7]. We previously reported that the serum lipid peroxide level increases with age but that the rate of increase is different between women and men; that is, serum lipid peroxide levels of 30-50 years old women are significantly lower than those of men in the same age category [8]. As to the reason for this difference, we suspected the effect of female hormones and found in in vitro experiments that estrogens have an antioxidant activity as expected from the presence of a phenolic hydroxyl group in

*To whom correspondence should be addressed. 
their structure [9]. We also reported from in vivo experiments that subcutaneous injection of estrogen or its metabolite catecholestrogen brought about a decrease in lipid peroxide levels in the serum and liver of mice [10]. The antioxidant activity of catecholestrogens was recognized by Wollenberg et al. [11] and Nakano et al. [12] in their in vitro experiments. In addition, we found that serum and liver lipid peroxide levels of ovariectomized mice were significantly increased and that these increases were suppressed by the administration of estrogen or catecholestrogen [13]. Our clinical study also revealed that the serum lipid peroxide level of women was significantly increased after bilateral ovariectomy [14]. These results support the idea that estrogens and catecholestrogens may play a role as an endogenous antioxidant.

As is well known, lipid peroxides are generated by radiation and have deleterious effects on organs and tissues. Since catecholestrogens were found to possess a potent antioxidant activity, one would expect that catecholestrogens would have a protective activity against radiation injury. The present study was undertaken to test this assumption in mice irradiated with ${ }^{60} \mathrm{Co} \gamma$-ray.

\section{MATERIALS AND METHODS}

Animals. Male mice of the BALB/c strain (10 weeks old, $25 \pm 2 \mathrm{~g}$ ) were used. They were fed a commercial laboratory chow (CE-2, Clea Japan, Inc., Tokyo) and given water ad libitum.

Chemicals. Estrone $\left(\mathrm{E}_{1}\right)$ and $17 \beta$-estradiol $\left(\mathrm{E}_{2}\right)$ were purchased from Nacalai Tesque Inc., Kyoto; estriol $\left(\mathrm{E}_{3}\right)$, 2-hydroxyestrone (2-OHE $\mathrm{H}_{1}$ ), 2-hydroxyestradiol $\left(2-\mathrm{OHE}_{2}\right)$, 2-hydroxyestriol $\left(2-\mathrm{OHE}_{3}\right)$, 4-hydroxyestradiol $\left(4-\mathrm{OHE}_{2}\right), 2$-methoxyestrone (2-MeOE 1 ), 2-methoxyestradiol (2- $\mathrm{MeOE}_{2}$ ), and 2-methoxyestriol (2$\mathrm{MeOE}_{3}$ ), from Sigma Chemical Co., St. Louis, MO; and carboxymethyl cellulose sodium salt (CMC), glutathione, and $d l-\alpha$-tocopheryl acetate, from Wako Pure Chemical Industries, Ltd., Osaka.

Each of these drugs was suspended in $1 \% \mathrm{CMC}$ and injected subcutaneously $3 \mathrm{~h}$ before and $3 \mathrm{~h}$ after the irradiation. The mice of the control group were given the same volume of $1 \% \mathrm{CMC}$.

${ }^{60} \mathrm{Co} \gamma$-ray irradiation. Mice were placed in a restrainer and given wholebody irradiation at a dose rate of $0.84-0.96 \mathrm{~Gy} / \mathrm{min}$ with a ${ }^{60} \mathrm{Co}$ irradiation apparatus (RTGS-2DM, Shimadzu, Kyoto). The total dose was $8 \mathrm{~Gy}$.

Measurement of lipid peroxide level and lipids. Lipid peroxide level in the liver was measured by the method of Ohkawa et al. [15] and expressed in terms of malondialdehyde. Lipids in the liver were extracted by the method of Folch et al. [16] from $20 \%$ liver homogenates in physiological saline, and the amounts of total cholesterol, triglycerides, and phospholipids were measured by use of respective reagent kits purchased from Kyowa Medex Co., Ltd., Tokyo.

Statistical analysis. Experimental values were analyzed by the Student's $t$-test and chi-square test. 


\section{RESULTS}

Effect of interval between 2-OHE injection and radiation on survival rate of lethally irradiated $B A L B / c$ mice

From our previous observation that subcutaneous injection of $2-\mathrm{OHE}_{2}$ was effective to suppress an increase in the lipid peroxide level of ovariectomized mice [13], we adopted the subcutaneous injection route for the administration of $2-\mathrm{OHE}_{2}$ to check its potency. First, we examined the effect of the interval between the injection and the irradiation on the survival rate. $2-\mathrm{OHE}_{2}$ was injected into male BALB/c mice at a dose of $2 \mathrm{mg} / \mathrm{kg}$ body weight either $15 \mathrm{~min}, 1 \mathrm{~h}, 3 \mathrm{~h}$, or 6 $\mathrm{h}$ before and after the irradiation. We found that the survival rate of mice 30 days after the irradiation was $30 \%$ when $2-\mathrm{OHE}_{2}$ was given $15 \mathrm{~min}$ before and $15 \mathrm{~min}$ after the irradiation, and that the rate reached maximum (ca. 70\%) when the drug was injected $1-6 \mathrm{~h}$ before and after the irradiation.

Then, $2-\mathrm{OHE}_{2}$ was given to the mice according to the protocol shown in Table 1; viz, $3 \mathrm{~h}$ before and $3 \mathrm{~h}$ after the irradiation (group 1); once $3 \mathrm{~h}$ before the irradiation (group 2); and once $3 \mathrm{~h}$ after the irradiation (group 3). The maximal survival rate was observed in the mice of group 1 . The rate of groups 2 and 3 was lower than that of group 1, but higher as compared with that of the control (group 4). These results indicate that the treatment both before and after the irradiation is necessary to obtain the maximum effect of $2-\mathrm{OHE}_{2}$.

Radioprotective effect of catecholestrogens on lethally irradiated $B A L B / c$ mice

Under the optimum conditions for the radioprotection of $2-\mathrm{OHE}_{2}$ described above, comparison among the three catecholestrogens was made. Each catecholestrogen was given at a dose of $2 \mathrm{mg} / \mathrm{kg}$ body weight $3 \mathrm{~h}$ before and $3 \mathrm{~h}$ after the whole-body irradiation with ${ }^{60} \mathrm{Co} \gamma$-ray, and the survival of the mice was followed for 30 days (Fig. 1). In the mice of control group, the first death occurred on the 10 th day after the irradiation, and the percent survival of the mice after 30 days was

Table 1. Effect of different protocol of 2-OHE ${ }_{2}$ administration on survival of mice after ${ }^{60} \mathrm{Co} \gamma$-irradiation.

\begin{tabular}{|c|c|c|c|c|}
\hline \multirow{2}{*}{ Group } & \multicolumn{2}{|c|}{ Administration at } & \multirow{2}{*}{ Survival } & \multirow{2}{*}{$\%$} \\
\hline & $3 \mathrm{~h}$ before & $3 \mathrm{~h}$ after & & \\
\hline 1 & $2-\mathrm{OHE}_{2}$ & $2-\mathrm{OHE}_{2}$ & $13 / 20$ & $65^{* *}$ \\
\hline 2 & $2-\mathrm{OHE}_{2}$ & - & $8 / 20$ & $40^{*}$ \\
\hline 3 & - & $2-\mathrm{OHE}_{2}$ & $5 / 20$ & 25 \\
\hline 4 & - & - & $1 / 20$ & 5 \\
\hline
\end{tabular}

Mice received whole-body irradiation with an $8-\mathrm{Gy}$ single dose of ${ }^{60} \mathrm{Co} \gamma$-ray. 2-OHE $\mathrm{OHas}_{2}$ subcutaneously injected at a dose of $2 \mathrm{mg} / \mathrm{kg}$ body weight $3 \mathrm{~h}$ before and $3 \mathrm{~h}$ after or once either before or after the irradiation as described under "Materials and Methods." Number of mice in each group was 20. Significant difference from the control (group 4) as analyzed by the chi-square test: ${ }^{*} p<0.05 ;{ }^{*} p<0.01$.

Vol. 15, No. 1, 1993 
only 5\%. When 2-OHE 2 was injected, the onset of the first death was delayed to the 15 th day after the irradiation, and the survival rate after 30 days remarkably increased to $70 \%$. In the case of mice injected with $2-\mathrm{OHE}_{1}$ or $2-\mathrm{OHE}_{3}$, their survival rate was always higher than that of the control animals. The injection with $d l$ - $\alpha$-tocopheryl acetate also resulted in a significant protection until the 21 st day.

Table 2 shows the survival rate 30 days after the irradiation of mice given each of various test drugs. Among them, $2-\mathrm{OHE}_{2}$ alone remarkably protected mice from death. The injection with $2-\mathrm{OHE}_{1}, 2-\mathrm{OHE}_{3}, \mathrm{E}_{3}$, or $d l$ - $\alpha$-tocopheryl acetate brought about lower degrees of protection.

Effect of dosage of 2-OHE $E_{2}$ on the survival rate of lethally irradiated $B A L B / c$ mice

As shown in Table 3 , the effect of $2-\mathrm{OHE}_{2}$ against radiation injury increased in a dose-dependent manner. The effective dose $\left(\mathrm{ED}_{50}\right)$, which gives $50 \%$ protection, was calculated to be about $0.8 \mathrm{mg} / \mathrm{kg}$ body weight.

Effect of 2-OHE $E_{2}$ on liver lipid peroxide level of lethally irradiated $B A L B / c$ mice

Casarett [17] described that there are three phases of the radiation syndrome in the rat after an 8-Gy single dose of whole-body $\gamma$-ray irradiation: viz., 1) an initial phase up to 4 days after the irradiation, in which prostration, fasting, and

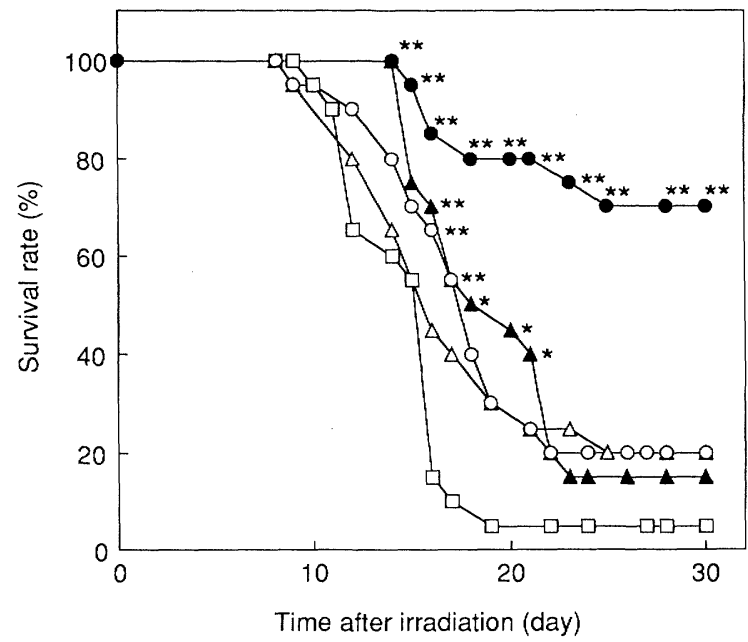

Fig. 1. Effect of catecholestrogens on the survival rate of mice after ${ }^{60} \mathrm{Co} \gamma$-ray irradiation. Mice received whole-body irradiation with an 8 -Gy single dose of ${ }^{60} \mathrm{Co} \gamma$-ray. Each catecholestrogen was injected $3 \mathrm{~h}$ before and $3 \mathrm{~h}$ after the irradiation as described under "Materials and Methods." $\mathrm{O}, 2-\mathrm{OHE}_{1} ; \bullet, 2-\mathrm{OHE}_{2} ; \Delta, 2-\mathrm{OHE}_{3} ; \Delta, d l$ - $\alpha$-tocopheryl acetate; $\square$, control. Number of mice in each group was 20. Significant difference from the control as analyzed by the chi-square test: ${ }^{*} p<0.05 ;{ }^{* *} p<0.01$.

J. Clin. Biochem. Nutr. 
Table 2. Effect of catecholestrogens, their monomethyl ethers, and estrogens on survival of mice after ${ }^{60} \mathrm{Co} \gamma$-irradiation.

\begin{tabular}{lcc}
\hline Test sample & Survival & \% \\
\hline $2-\mathrm{OHE}_{1}$ & $4 / 20$ & 20 \\
$2-\mathrm{OHE}_{2}$ & $14 / 20$ & $70^{*}$ \\
$2-\mathrm{OHE}_{3}$ & $4 / 20$ & 20 \\
$4-\mathrm{OHE}_{2}$ & $0 / 20$ & 0 \\
$2-\mathrm{MeOE}_{1}$ & $0 / 20$ & 0 \\
$2-\mathrm{MeOE}_{2}$ & $0 / 20$ & 0 \\
$2-\mathrm{MeOE}_{3}$ & $0 / 20$ & 0 \\
$\mathrm{E}_{1}$ & $0 / 20$ & 0 \\
$\mathrm{E}_{2}$ & $1 / 20$ & 5 \\
$\mathrm{E}_{3}$ & $4 / 20$ & 20 \\
$d l-\alpha-$ Tocopheryl acetate & $3 / 20$ & 15 \\
Glutathione & $1 / 20$ & 5 \\
Control & $1 / 20$ & 5 \\
\hline
\end{tabular}

Mice received whole-body irradiation with an 8 -Gy single dose of ${ }^{60} \mathrm{Co} \gamma$-ray. Each test compound was subcutaneously injected at a dose of $2 \mathrm{mg} / \mathrm{kg}$ body weight $3 \mathrm{~h}$ before and 3 $\mathrm{h}$ after the irradiation as described under "Materials and Methods." Number of mice in each group was 20. Significant difference from the control as analyzed by the chi-square test: ${ }^{*} p<0.01$.

Table 3. Effect of dose of $2-\mathrm{OHE}_{2}$ on survival of mice after ${ }^{60} \mathrm{Co} \gamma$-irradiation.

\begin{tabular}{ccc}
\hline $\begin{array}{c}\text { Dose of } 2-\mathrm{OHE}_{2} \\
(\mathrm{mg} / \mathrm{kg})\end{array}$ & Survival & $\%$ \\
\hline 4 & $14 / 20$ & $70^{* *}$ \\
2 & $13 / 20$ & $65^{* *}$ \\
1 & $11 / 20$ & $55^{* *}$ \\
0.5 & $9 / 20$ & $45^{*}$ \\
0.25 & $0 / 20$ & 0 \\
0 & $1 / 20$ & 5 \\
\hline
\end{tabular}

Mice received whole-body irradiation with an 8-Gy single dose of ${ }^{60} \mathrm{Co} \gamma$-ray. 2-OHE ${ }_{2}$ was subcutaneously injected $3 \mathrm{~h}$ before and $3 \mathrm{~h}$ after the irradiation as described under "Materials and Methods." Number of mice in each group was 20. Significant difference from the control as analyzed by the chi-square test: ${ }^{*} p<0.05 ;{ }^{* *} p<0.01$.

diarrhoea occur; 2) a remission phase from 5 to 7 days, in which the animals regain normal feeding and mobility; and 3) a final phase from 8 days, in which hemorrhage occurs, which leads to death. Since a marked increase in the lipid peroxide level in the liver was observed in the initial phase [18], we examined the change in the lipid peroxide level in the liver of mice 4 days after the irradiation. As shown in Table 4, the level was increased by the irradiation to one over twice that of the control. This increase was significantly suppressed by the injection of $2-\mathrm{OHE}_{2}$. When the lipid peroxide level was expressed per mg of lipids, the same results were obtained. 
Table 4. Effect of $2-\mathrm{OHE}_{2}$ on liver lipid peroxide level in mice after ${ }^{60} \mathrm{Co} \gamma$-irradiation.

\begin{tabular}{|c|c|c|c|c|}
\hline \multirow{2}{*}{ Group } & \multirow{2}{*}{${ }^{60} \mathrm{Co}$} & \multirow{2}{*}{$2-\mathrm{OHE}_{2}$} & \multicolumn{2}{|c|}{ Lipid peroxide level } \\
\hline & & & (nmol/100 mg liver) & (nmol/mg lipids) \\
\hline 1 & - & - & $51.9 \pm 5.4$ & $21.7 \pm 2.1$ \\
\hline 2 & + & - & $101.6 \pm 8.5^{*}$ & $41.1 \pm 2.2^{*}$ \\
\hline 3 & + & + & $43.0 \pm 6.9$ & $21.6 \pm 2.5$ \\
\hline
\end{tabular}

Mice received whole-body irradiation with an 8 -Gy single dose of ${ }^{60} \mathrm{Co} \gamma$-ray. $2-\mathrm{OHE}_{2}$ was subcutaneously injected at a dose of $2 \mathrm{mg} / \mathrm{kg}$ body weight as described under "Materials and Methods." Lipid peroxide level was measured 4 days after the irradiation. Mean $\pm \mathrm{SE}$ is given. Number of mice in each group was 9 . Significant difference from the values of group 1 as analyzed by the Student's $t$-test: ${ }^{*} p<0.01$.

\section{DISCUSSION}

The present data indicate for the first time that catecholestrogens have a considerable radioprotective effect in vivo. Although the details of the mechanism for the radioprotective effect of catecholestrogens remain to be elucidated, their antioxidant activity is principally postulated to explain the effect. Among the various estrogens, catecholestrogens, and methoxy derivatives of catecholestrogens examined in the present study, $2-\mathrm{OHE}_{2}$ was most effective in protecting mice from radiation death. As to the antioxidant activity in vitro, it was reported that the potency of $2-\mathrm{OHE}_{2}$ is almost the same as that of 2-OHE $\mathrm{O}_{1}$ [12]. However, the present results indicate that the radioprotective effect of $2-\mathrm{OHE}_{1}$ was lower than that of $2-\mathrm{OHE}_{2}$. This result might be ascribable to the fact that the plasma metabolic clearance rate of $2-\mathrm{OHE}_{1}$ is higher than that of $2-\mathrm{OHE}_{2}$ [19]. 2-OHE was ineffective in the present in vivo radioprotection experiments, probably reflecting that in vitro antioxidant activity of $2-\mathrm{OHE}_{3}$ is lower than that of $2-\mathrm{OHE}_{2}$ [12]. Further study is needed to compare the bioavailability of these catecholestrogens for a better understanding of the reason(s) for their different potency in vivo.

\section{REFERENCES}

1. Steinberg, D., Parthasarathy, S., Carew, T.E., Khoo, J.C., and Witztum, J.L. (1989): Beyond cholesterol: Modifications of low-density lipoprotein that increase its atherogenicity. $N$. Engl. J. Med., 320, 915-924.

2. Henning, B., and Chow, C.K. (1988): Lipid peroxidation and endothelial cell injury: Implications in atherosclerosis. Free Radical Biol. Med., 4, 99-106.

3. Yagi, K. (1988): Lipid peroxides in atherosclerosis, in The Role of Oxygen in Chemistry and Biochemistry, ed. by Ando, M. and Moro-oka, Y., Elsevier Science Publishers B.V., Amsterdam, pp. 383-390.

4. Bhuyan, K.C., Bhuyan, D.K., Kuck, J.F.R., Jr., Kuck, K.D., and Kern, H.L. (1982/1983): Increased lipid peroxidation and altered membrane functions in Emory mouse cataract. Curr. Eye Res., 2, 597-606.

5. Zigler, J.S., Jr., and Hess, H.H. (1985): Cataracts in the Royal College of Surgeons rat: Evidence for initiation by lipid peroxidation products. Exp. Eye Res., 41, 67-76. 
6. Yagi, K., Komura, S., Ihara, N., Abe, H., Konishi, H., and Arichi, S. (1985): Serum lipid peroxide levels in rats with inherited cataracts. J. Appl. Biochem., 7, 202-206.

7. Yagi, K., Yoshino, K., Komura, S., Kondo, K., and Ohishi, N. (1988): Lipid peroxide levels in the senescence-accelerated mouse. J. Clin. Biochem. Nutr., 5, 21-27.

8. Suematsu, T., Kamada, T., Abe, H., Kikuchi, S., and Yagi, K. (1977): Serum lipoperoxide level in patients suffering from liver diseases. Clin. Chim. Acta, 79, 267-270.

9. Yagi, K., and Komura, S. (1986): Inhibitory effect of female hormones on lipid peroxidation. Biochem. Int., 13, 1051-1055.

10. Yoshino, K., Komura, S., Watanabe, I., Nakagawa, Y., and Yagi, K. (1987): Effect of estrogens on serum and liver lipid peroxide levels in mice. J. Clin. Biochem. Nutr., 3, 233240 .

11. Wollenberg, P., Scheulen, M., Bolt, H.M., Kappus, H., and Remmer, H. (1976): Wirkung von 2-hydroxyöstradiol-17 $\beta$ auf den NADPH-abhängigen Elektronentransport in Rattenleber-Mikrosomen in vitro. Hoppe-Seyler's Z. Chem., 357, 351-357.

12. Nakano, M., Sugioka, K., Naito, I., Takekoshi, S., and Niki, E. (1987) Novel and potent biological antioxidants on membrane phospholipid peroxidation: 2-hydroxy estron and 2-hydroxy estradiol. Biochem. Biophys. Res. Commun., 142, 919-924.

13. Nakagawa, Y., Yoshino, K., Komura, S., Ishihara, M., and Yagi, K. (1989): Effect of ovariectomy on serum and liver lipid peroxide levels of female mice. J. Clin. Biochem. Nutr., 6, 87-94.

14. Asada, Y., Komura, S., Ohishi, N., Kasugai, M., Suganuma, N., Mizutani, S., Tomoda, Y., and Yagi, K. (1990): Effect of ovariectomy on serum lipid peroxide levels in women. J. Clin. Biochem. Nutr., 8, 247-252.

15. Ohkawa, H., Ohishi, N., and Yagi, K. (1979): Assay for lipid peroxides in animal tissues by thiobarbituric acid reaction. Anal. Biochem., 95, 351-358.

16. Folch, J., Ascoli, I., Lees, M., Meath, J.A., and LeBaron, F.N. (1951): Preparation of lipide extracts from brain tissue. J. Biol. Chem., 191, 833-841.

17. Casarett, A.P. (1968): Radiation Biology, Prentice Hall, Englewood Clifts.

18. Kergonou, J.-F., Bernard, P., Braquet, M., and Rocquet, G. (1981): Effect of whole-body gamma irradiation on lipid peroxidation in rat tissues. Biochimie, 63, 555-559.

19. Kono, S., Merriam, G.R., Brandon, D.D., Loriaux, D.L., and Lipsett, M.B. (1982): Radioimmunoassay and metabolism of the catechol estrogen 2-hydroxyestradiol. J. Clin. Endocrinol. Metab., 54, 150-154. 